\title{
Metabolic Acidosis Alters Expression of Slc22 Transporters in Mouse Kidney
}

\author{
Janine Gottier Nwafor ${ }^{a}$ Marta Nowik ${ }^{a}$ Naohiko Anzai ${ }^{b}$ Hitoshi Endou $^{c}$ \\ Carsten A. Wagner ${ }^{a}$ \\ anstitute of Physiology and Zurich Center for Integrative Human Physiology, University \\ of Zurich, Zurich, Switzerland; 'b Department of Pharmacology, Chiba University Graduate \\ School of Medicine, Chiba, Japan; ' Department of Pharmacology and Toxicology, Kyorin \\ University School of Medicine, Tokyo, Japan
}

\section{Keywords}

Acidosis · Proximal tubule · Drug transporter · Organic cation transporter

\begin{abstract}
Introduction: The kidneys play a central role in eliminating metabolic waste products and drugs through transporter-mediated excretion along the proximal tubule. This task is mostly achieved through a variety of transporters from the solute carrier family 22 (SLC22) family of organic cation and anion transporters. Metabolic acidosis modulates metabolic and renal functions and also affects the clearance of metabolites and drugs from the body. We had previously shown that induction of metabolic acidosis in mice alters a large set of transcripts, among them also many transporters including transporters from the Slc22 family. Objective: Here we further investigated the impact of acidosis on Slc22 family members. Methods: Metabolic acidosis was induced for 2 or 7 days with $\mathrm{NH}_{4} \mathrm{Cl}$, some animals also received the uricase inhibitor oxonic acid for comparison. Expression of transporters was studied by qPCR and immunoblotting. Results: $\mathrm{NH}_{4} \mathrm{Cl}$ induced no significant changes in plasma or urine uric acid levels but caused downregulation of Slc22a1 (Oct1), Slc22a6 (Oat1), Slc22a19 (Oat5), and Slc22a12 (Urat1) at mRNA level. In contrast, Slc22a4 mRNA (Octn1) was upregulated. On protein level, $\mathrm{NH}_{4} \mathrm{Cl}$ increased Octn1 (after 7 days) and Urat1 (after 2 days) abundance and decreased Oat1 (after 2 days) and Urat1 (after 7 days). Oxonic acid had no impact on protein abundance of any of the transporters tested. Conclusion: In summary, metabolic acidosis alters expression of several transporters involved in renal excretion of metabolic waste products and drugs. This may have implications for drug kinetics and clearance of waste metabolites.
\end{abstract}




\section{Kidney \\ Blood Pressure \\ Research}

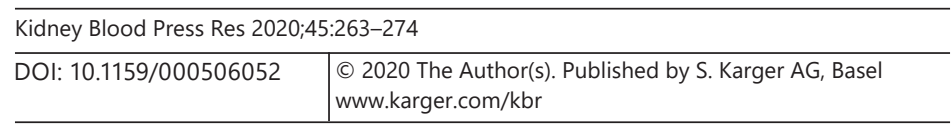

Gottier Nwafor et al.: Metabolic Acidosis Alters Expression of Slc22 Transporters in Mouse Kidney

\section{Introduction}

The renal proximal tubule plays a key role in eliminating endogenous metabolic waste products as well as in the excretion of water-soluble exogenous drugs and their metabolites. Various members of the solute carrier transporter family 22 (SLC22) contribute to this important task. They belong to at least 2 subgroups of transporters, organic anion transporters (OAT) and organic cation transporter (OCT; [1, 2]). Several OAT and OCT transporters are expressed in mammalian kidney and contribute to the excretion of organic anions and cations including uric acid. OAT and OCT transporters are expressed mainly in the proximal tubule and are located on either the luminal (apical) or basolateral membrane, thereby mediating uptake from/release into blood and reabsorption from/excretion into urine of various substrates. Major substrates of these transporters include para-amino hippurate, $\alpha$-ketoglutarate, and urate as well as a plethora of cationic or anionic drugs [2]. Among these transporters, OAT1 (SLC22A6) and OCT1 (SLC22A1) are localized at the basolateral site, whereas OCTN1 (SLC22A4), URAT1 (SLC22A12), and OAT5 (SLC22A10) are expressed at the luminal site of proximal tubule cells [2].

Previously, we had performed a genome-wide transcriptome analysis of mouse kidney after 2 and 7 metabolic acidosis induced by $\mathrm{NH}_{4} \mathrm{Cl}$-supplementation to drinking water [3]. Surprisingly, we found a large number $(>3,000)$ of transcripts to be regulated including $>100$ members of the solute carrier family (SLC) highlighting the importance of transport processes in the kidney and the major impact of acidosis. Among the SLC subfamilies, we found members of the SLC22 family of organic anion and cation transporters to be highly represented with 5 transporters being up- or downregulated during $\mathrm{NH}_{4} \mathrm{Cl}$ treatment [3]. Similarly, Gaowa et al. [4] showed in acutely acidotic rats (after 2 days of $\mathrm{NH}_{4} \mathrm{Cl}$ supplementation) that Oat3 was reduced while Oat1 and Oct1 remained unaffected [4].

The aim of the current study was to further study this regulation of Slc22 transporters by $\mathrm{NH}_{4} \mathrm{Cl}$-induced metabolic acidosis. Our results demonstrate distinct patterns of regulation of several major representatives of this important Slc family.

\section{Methods}

\section{Animals}

All experiments were performed on 12 weeks old C57BL/6J male mice. All experiments were performed according to Swiss Animal Welfare laws and approved by the local veterinary authority (Veterinäramt Zürich).

\section{Metabolic Cages}

To induce metabolic acidosis C57BL/6J mice were given $0.28 \mathrm{M} \mathrm{NH}_{4} \mathrm{Cl} / 2 \%$ sucrose in drinking water for 2 or 7 days. The control group received only $2 \%$ sucrose in drinking water for 7 days as described previously [3].

One group of mice received the uricase inhibitor oxonic acid (2\%) added to drinking water during the entire period of the experiment as described previously [5].

Each group consisted of 5 animals for each time point and treatment. Forty-eight hour prior sacrificing mice were housed in metabolic cages and had free access to standard mouse chow and drinking water ad libitum. Daily chow, water intake, and body weights were measured, and urine was collected under mineral oil. At the end of experiment, mice were anesthetized with ketamine-xylazine, and heparinised mixed arterial-venous blood was collected and analyzed immediately for $\mathrm{pH}$, blood gases, and electrolytes on a Radiometer ABL 800 (Radiometer, Copenhagen, Denmark) blood gas analyzer. Serum was collected and frozen until further analysis. Both kidneys were harvested and rapidly frozen in liquid nitrogen and stored at $-80^{\circ} \mathrm{C}$. 


\section{Kidney \\ Blood Pressure \\ Research}

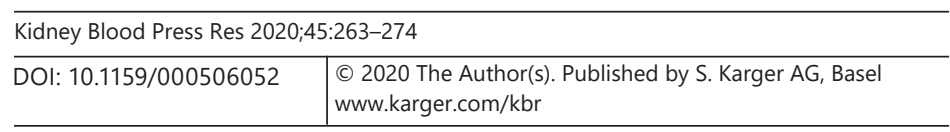

Gottier Nwafor et al.: Metabolic Acidosis Alters Expression of Slc22 Transporters in Mouse Kidney

Urinary $\mathrm{pH}$ was measured using a pH microelectrode (691 pH Meter, Metroholm). Urinary creatinine was measured by the Jaffe method [6]. Ammonium in urine was measured by the method of Berthelot [7]. Urinary and serum phosphate was measured using a commercial kit (Sigma Diagnostics, Munich, Germany). Serum and urine uric acid were measured using a colorimetric test according to the manufacturers protocol (BioAssay Systems, Hayward, CA, USA). Urinary electrolytes $\left(\mathrm{Na}^{+}, \mathrm{K}^{+}, \mathrm{Ca}^{2+}, \mathrm{Mg}^{2+}, \mathrm{Cl}^{-}, \mathrm{SO}_{4}{ }^{2-}\right)$ were measured by ion chromatography (Metrohm ion chromatograph, Herisau, Switzerland).

\section{RNA Extraction and Reverse Transcription}

Kidneys were harvested and rapidly frozen in liquid nitrogen. Snap-frozen kidneys (5 kidneys for each condition) were homogenized in RLT-Buffer (Qiagen, Basel, Switzerland) supplemented with $\beta$-mercaptoethanol to a final concentration of $1 \%$. Total RNA was extracted from $200 \mu \mathrm{L}$ aliquots of each homogenized sample using the RNeasy Mini Kit (Qiagen) according to the manufacturer's instructions. Quality and concentration of the isolated RNA preparations were analyzed by the ND-1000 spectrophotometer (NanoDrop Technologies). Total RNA samples were stored at $-80^{\circ} \mathrm{C}$. Each RNA sample was diluted to 100 $\mathrm{ng} / \mu \mathrm{L}$ and $3 \mu \mathrm{L}$ used as a template for reverse transcription using the TaqMan Reverse Transcription Kit (Applied Biosystems, Forter City, CA, USA). For reverse transcription, $300 \mathrm{ng}$ of RNA template were diluted in a 40- $\mu \mathrm{L}$ reaction mix that contained (final concentrations) RT buffer (1×), $\mathrm{MgCl}_{2}(5.5 \mathrm{mM})$, random hexamers $(2.5 \mu \mathrm{M})$, RNase inhibitor $(0.4 \mathrm{U} / \mu \mathrm{L})$, the multiscribe reverse transcriptase enzyme $(1.25 \mathrm{U} / \mu \mathrm{L})$, dNTP mix (500 $\mu \mathrm{M}$ each), and RNase-free water.

\section{Quantitative Real-Time PCR}

Semi-quantitative real-time qRT-PCR was performed on the ABI PRISM 7700 Sequence Detection System (Applied Biosystems). Primers for all genes of interest were designed using Primer Express software from Applied Biosystems (Table 1). Primers were chosen to result in amplicons no longer than 150 bp spanning intron-exon boundaries to exclude genomic DNA contamination. The specificity of all primers was first tested on mRNA derived from kidney and always resulted in a single product of the expected size (data not shown). Probes were labeled with the reporter dye FAM at the $5^{\prime}$ end and the quencher dye TAMRA at the $3^{\prime}$ end (Microsynth, Balgach, Switzerland). Real-time PCR reactions were performed using TaqMan Universal PCR Master Mix (Applied Biosystems). Briefly, $3.5 \mu \mathrm{L}$ cDNA, $1 \mu \mathrm{L}$ of each primer $(25 \mu \mathrm{M}), 0.5 \mu \mathrm{L}$ labelled probe $(5 \mu \mathrm{M}), 6.5 \mu \mathrm{L}$ RNAse free water, $12.5 \mu \mathrm{L}$ TaqMan Universal PCR Master Mix reached $25 \mu \mathrm{L}$ of final reaction volume. Reaction conditions were denaturation at $95^{\circ} \mathrm{C}$ for $10 \mathrm{~min}$ followed by 40 cycles of denaturation at $95^{\circ} \mathrm{C}$ for $15 \mathrm{~s}$ and annealing/elongation at $60^{\circ} \mathrm{C}$ for $60 \mathrm{~s}$ with auto ramp time. All reactions were run in duplicate. For analysing the data, the threshold was set to 0.06 as this value had been determined to be in the linear range of the amplification curves for all mRNAs in all experimental runs. The expression of gene of interest was calculated in relation to hypoxanthine guanine phosphoribosyl transferase. Relative expression ratios were calculated as $\mathrm{R}=2^{\text {(Ct [hypoxanthine guanine phos- }}$ phoribosyl transferase]) - $\mathrm{Ct}$ [test gene], where Ct represents the cycle number at the threshold 0.06 .

\section{Brush Border Membrane Vesicles Preparation}

Mice were anaesthetized with ketamine-xylazine intraperitoneally and kidneys were removed and rapidly frozen in liquid nitrogen. Brush border membranes were prepared as described previously using the $\mathrm{Mg}^{2+}$-precipitation technique $[8,9]$ and further used for immunoblotting. Total membrane protein preparations were obtained as previously described [10]. Briefly, total kidneys were homogenized in an ice-cold K-HEPES buffer $(200 \mathrm{mmol} / \mathrm{L}$ mannitol, $80 \mathrm{mmol} / \mathrm{L} \mathrm{K}-\mathrm{HEPES}, 41 \mathrm{mmol} / \mathrm{L} \mathrm{KOH}, \mathrm{pH}$ 7.5) with pepstatin, leupeptin, K-ethyl- 
Kidney

Blood Pressure

Research \begin{tabular}{l|l}
\hline Kidney Blood Press Res 2020;45:263-274 \\
\hline DOI: 10.1159/000506052 & $\begin{array}{l}\text { @ 2020 The Author(s). Published by S. Karger AG, Basel } \\
\text { www.karger.com/kbr }\end{array}$ \\
\hline Gottier Nwafor et al.: Metabolic Acidosis Alters Expression of SIc22 Transporters in
\end{tabular} Mouse Kidney

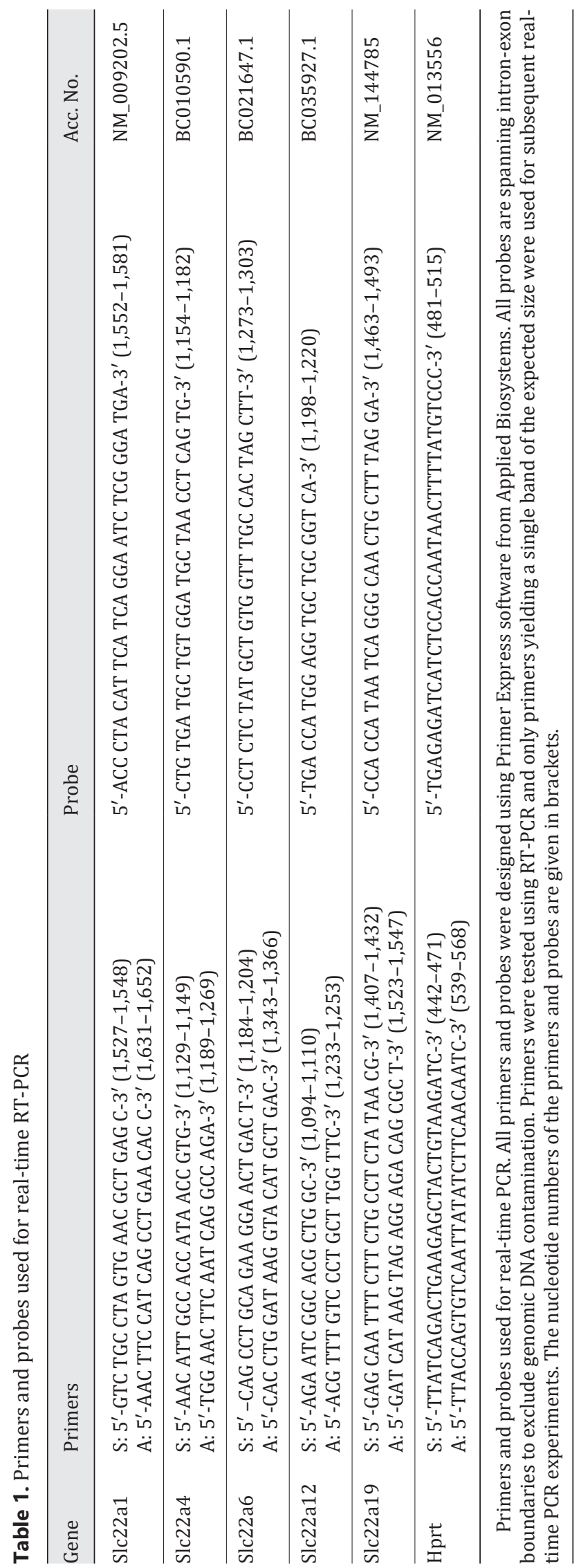


Table 2. Metabolic cages and blood gas analysis

\begin{tabular}{|c|c|c|c|c|}
\hline Groups & Control & $\begin{array}{l}\mathrm{NH}_{4} \mathrm{Cl} \\
2 \text { days }\end{array}$ & $\begin{array}{l}\mathrm{NH}_{4} \mathrm{Cl} \\
7 \text { days }\end{array}$ & $\begin{array}{l}\text { Oxonic acid } \\
7 \text { days }\end{array}$ \\
\hline \multicolumn{5}{|l|}{ Urine, mean \pm SD } \\
\hline $\mathrm{pH}$ & $6.34 \pm 0.05$ & $5.4 \pm 0.05^{* * *}$ & $5.37 \pm 0.04^{* * *}$ & $6.17 \pm 0.05$ \\
\hline $\mathrm{NH}_{3} / \mathrm{NH}_{4}{ }^{+}, \mathrm{mM} / \mathrm{crea}, \mathrm{mg} / \mathrm{dL}$ & $4.18 \pm 0.98$ & $41.50 \pm 5.99 * *$ & $38.89 \pm 7.72^{*}$ & $5.98 \pm 0.70$ \\
\hline $\mathrm{TA}, \mathrm{mM} / \mathrm{crea}, \mathrm{mg} / \mathrm{dL}$ & $0.095 \pm 0.02$ & $0.073 \pm 0.005$ & $0.071 \pm 0.004$ & $0.091 \pm 0.004$ \\
\hline $\mathrm{NAE}, \mathrm{mM} / \mathrm{crea}, \mathrm{mg} / \mathrm{dL}$ & $4.10 \pm 0.86$ & $41.43 \pm 5.99 * *$ & $38.82 \pm 7.73^{*}$ & $5.89 \pm 0.70$ \\
\hline $\mathrm{Na}^{+}, \mathrm{mM} / \mathrm{crea}, \mathrm{mg} / \mathrm{dL}$ & $15.3 \pm 2.9$ & $11.5 \pm 0.9$ & $12.8 \pm 0.7$ & $7.0 \pm 1.6^{*}$ \\
\hline $\mathrm{K}^{+}, \mathrm{mM} / \mathrm{crea}, \mathrm{mg} / \mathrm{dL}$ & $36.6 \pm 8.7$ & $27.0 \pm 2.6$ & $29.6 \pm 1.7$ & $35.6 \pm 7.3$ \\
\hline $\mathrm{Cl}^{-}, \mathrm{mM} / \mathrm{crea}, \mathrm{mg} / \mathrm{dL}$ & $27.7 \pm 4.4$ & $90.00 \pm 8.7^{* * *}$ & $108.2 \pm 5.7^{* * *}$ & $21.0 \pm 0.9$ \\
\hline $\begin{array}{l}\text { Uric acid, mM/crea, mg/dL } \\
\text { Blood, mean } \pm \text { SD }\end{array}$ & $13.2 \pm 2.1$ & $8.5 \pm 0.5$ & $7.5 \pm 0.4$ & $15.0 \pm 2.7$ \\
\hline $\mathrm{pH}$ & $7.23 \pm 0.02$ & $7.1 \pm 0.03^{*}$ & $7.22 \pm 0.03$ & $7.20 \pm 0.03$ \\
\hline $\mathrm{pCO}_{2}$ & $41.7 \pm 2.7$ & $44.2 \pm 2.4$ & $40.13 \pm 3.6$ & $44.1 \pm 1.1$ \\
\hline $\mathrm{HCO}_{3}^{-}, \mathrm{mM}$ & $16.9 \pm 1.1$ & $13.2 \pm 0.75^{*}$ & $14.5 \pm 1.7$ & $16.8 \pm 1.1$ \\
\hline $\mathrm{Na}^{+}, \mathrm{mM}$ & $143.5 \pm 1.7$ & $149.4 \pm 2.6$ & $149.8 \pm 1.2^{*}$ & $148.4 \pm 0.7^{*}$ \\
\hline $\mathrm{Cl}^{-}, \mathrm{mM}$ & $112.5 \pm 0.9$ & $122.6 \pm 0.7^{* * *}$ & $118.0 \pm 1.2^{*}$ & $116.0 \pm 0.5^{* *}$ \\
\hline $\mathrm{K}^{+}, \mathrm{mM}$ & $8.0 \pm 0.3$ & $7.4 \pm 0.3$ & $7.0 \pm 0.3$ & $6.9 \pm 0.4$ \\
\hline Uric acid, mg/dL & $9.0 \pm 0.9$ & $6.9 \pm 0.7$ & $8.4 \pm 0.5$ & $8.9 \pm 0.9$ \\
\hline Body weight, g & $25.7 \pm 0.5$ & $26.5 \pm 0.4$ & $24.9 \pm 0.3$ & $25.3 \pm 0.3^{*}$ \\
\hline
\end{tabular}

Blood gas and electrolytes in blood and urine from control mice and animals receiving $\mathrm{NH}_{4} \mathrm{Cl}$ for 2 or 7 days, or $2 \%$ oxonic acid for 7 days, respectively. Five animals were analyzed for each group.

${ }^{*} p>0.05,{ }^{* *} p>0.01,{ }^{* * *} p>0.001$ compared to control.

enedi-aminetetraacetic acid, and phenylmethylsulfonyl fluoride added as protease inhibitors. The samples were centrifuged at $1,000 \mathrm{~g}$ for $10 \mathrm{~min}$ at $4^{\circ} \mathrm{C}$ and the supernatant saved. Subsequently, the supernatant was centrifuged at $100,000 \mathrm{~g}$ for $1 \mathrm{~h}$ at $4^{\circ} \mathrm{C}$ and the resultant pellet resuspended in K-HEPES buffer containing protease inhibitors.

\section{Immunoblotting}

After measurement of the protein concentration (Bio-Rad, Hercules, CA, USA), $10 \mu \mathrm{g}$ of brush border membrane or $50 \mu \mathrm{g}$ of total membrane proteins were solubilized in Laemmli sample buffer, and SDS-PAGE was performed on a $10 \%$ polyacrylamide gel. For immunoblotting, the proteins were transferred electrophoretically to polyvinylidene fluoride membranes (Immobilon-P, Millipore, Bedford, MA, USA). After blocking with 5\% milk powder in Tris-buffered saline/0.1\% Tween-20 for $60 \mathrm{~min}$, the blots were incubated with the primary antibodies: rabbit anti-Octn1 1:1,000 (\#OCTN11-A, Alpha Diagnostics, San Antonio, TX, USA), rabbit anti-Urat-1 1:1,000 [11], rabbit anti-Oat-1 (\#OAT11-A, Alpha Diagnostics, San Antonio, TX, USA) 1:200, and mouse monoclonal anti- $\beta$-actin antibody (42 kD; Sigma, St. Louis, MO, USA; $1: 5,000$ ) either for $2 \mathrm{~h}$ at room temperature or overnight at $4{ }^{\circ} \mathrm{C}$. The membranes were then washed 3 times, blocked for $1 \mathrm{~h}$, and again incubated for $1 \mathrm{~h}$ at room temperature with the secondary goat antirabbit or donkey antimouse antibodies 1:5,000 linked to alkaline phosphatase (Promega, Madison, WI, USA). The protein signal was detected with the CDP Star chemilumescensce system (Roche Diagnostics, Basel, Switzerland) using the DIANA IIIchemiluminescence detection system (Raytest, Straubenhardt, Germany). All images were analyzed using appropriate software (Advanced Image Data Analyser AIDA, Raytest) to calculate the protein of interest/ $\beta$-actin ratio. 
Fig. 1. Plasma and urine uric acid. Uric acid levels were measured in plasma samples and in $24 \mathrm{~h}$ urine collections from control mice, mice receiving $\mathrm{NH}_{4} \mathrm{Cl}$ for 2 or 7 days, and mice receiving $2 \%$ oxonic acid. $n=5$ /group.

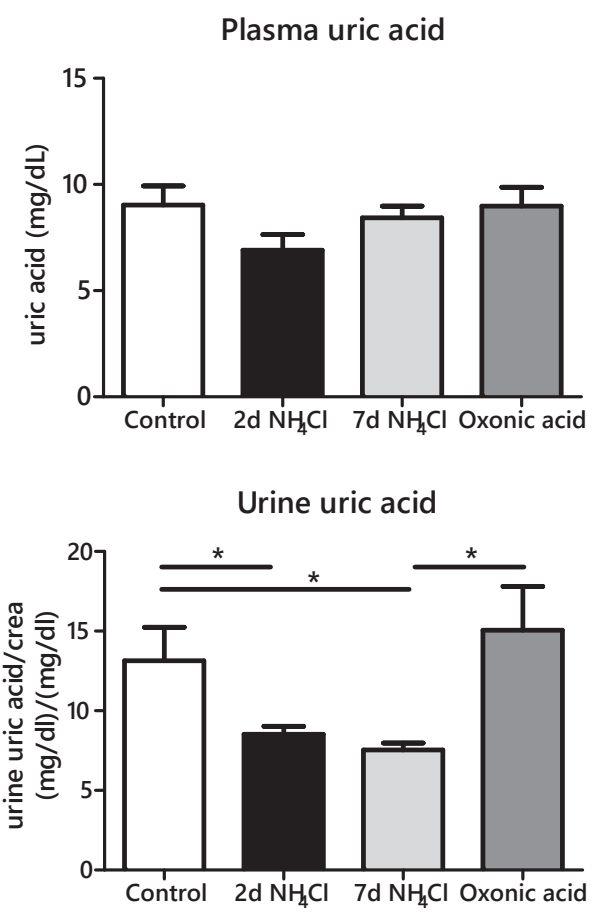

\section{Statistical Analysis}

Results are expressed as mean \pm SEM. All data were tested for significance using the ANOVA and unpaired Student test where appropriate. Only values with $p<0.05$ were considered as significant.

\section{Results}

Mice received $0.28 \mathrm{M} \mathrm{NH}_{4} \mathrm{Cl}$ for 2 or 7 days to induce metabolic acidosis as described previously [12-14]. One group of mice also received the uricase inhibitor oxonic acid (2\%) in order to test whether increased urate availability had a similar influence as $\mathrm{NH}_{4} \mathrm{Cl}$ on the expression of the transporters of interest. All treatments had a similar impact on body weight and food intake as assessed in metabolic cages (Table 2). As expected, $\mathrm{NH}_{4} \mathrm{Cl}$ induced an acid load with metabolic acidosis after 2 days which was mostly compensated by day 7. Plasma uric acid was lower after 2 days of $\mathrm{NH}_{4} \mathrm{Cl}$; however, the difference did not reach statistical significance. Urine uric acid excretion normalized to creatinine was lower in the animals receiving $\mathrm{NH}_{4} \mathrm{Cl}$ for 2 or 7 days. In contrast, animals receiving 2\% oxonic acid showed no difference in their uric acid/creatinine ratio as compared to control animals (Fig. 1, Table 2). This may reflect adaption to a new steady state of uric acid production and elimination.

Next we assessed the impact of $\mathrm{NH}_{4} \mathrm{Cl}$ or oxonic acid on transporters whose expression had been found to be altered by $\mathrm{NH}_{4} \mathrm{Cl}$ treatment in mice for 2 or 7 days [12]. Where possible and antibodies available to us, we tested also on concomitant changes in protein abundance.

The mRNA abundance of Slc22a1, the Oct1, was transiently and significantly reduced by 2 days of $\mathrm{NH}_{4} \mathrm{Cl}$ but returned to normal levels after 7 days of $\mathrm{NH}_{4} \mathrm{Cl}$. Oxonic acid had no effect on Slc22a1 mRNA expression (Fig. 2). The protein expression levels of Oct1 could not be investigated as none of the antibodies tested by us appeared to be specific enough. 
Kidney

Blood Pressure

Research

Fig. 2. Expression of the Oct1 in mouse kidney. Semi-quantitative RT-PCR was performed on total mRNA extracted from kidneys from control mice, mice receiving $\mathrm{NH}_{4} \mathrm{Cl}$ for 2 or 7 days, and mice receiving $2 \%$ oxonic acid. $n=5 /$ group, ${ }^{*} p<0.05$. OCT, organic cation transporter; SLC22, solute carrier family 22 .

Fig. 3. Regulation of the Octn1 cation transporter in mouse kidney. Semi-quantitative RT-PCR was performed on total mRNA and immunoblotting on brush border membranes extracted from kidneys from control mice, mice receiving $\mathrm{NH}_{4} \mathrm{Cl}$ for 2 or 7 days, and mice receiving $2 \%$ oxonic acid. Membranes were stripped and reprobed for $\beta$-actin to control for loading. Bar graphs show Octn1 protein abundance normalized to $\beta$-actin and expressed as percentage of the control group. $n=5 /$ group, ${ }^{*} p<0.05$, ${ }^{* *} p<0.01$, *** $p<0.001$. OCT, organic cation transporter; SLC22, solute carrier family 22 .

\begin{tabular}{l|l}
\hline Kidney Blood Press Res 2020;45:263-274 \\
\hline DOI: 10.1159/000506052 & $\begin{array}{l}\text { @ 2020 The Author(s). Published by S. Karger AG, Basel } \\
\text { www.karger.com/kbr }\end{array}$ \\
\hline \multicolumn{1}{l}{ Gottier Nwafor et al.: Metabolic Acidosis Alters Expression of SIc22 Transporters in }
\end{tabular}
Mouse Kidney

SIc22a1 - OCT1
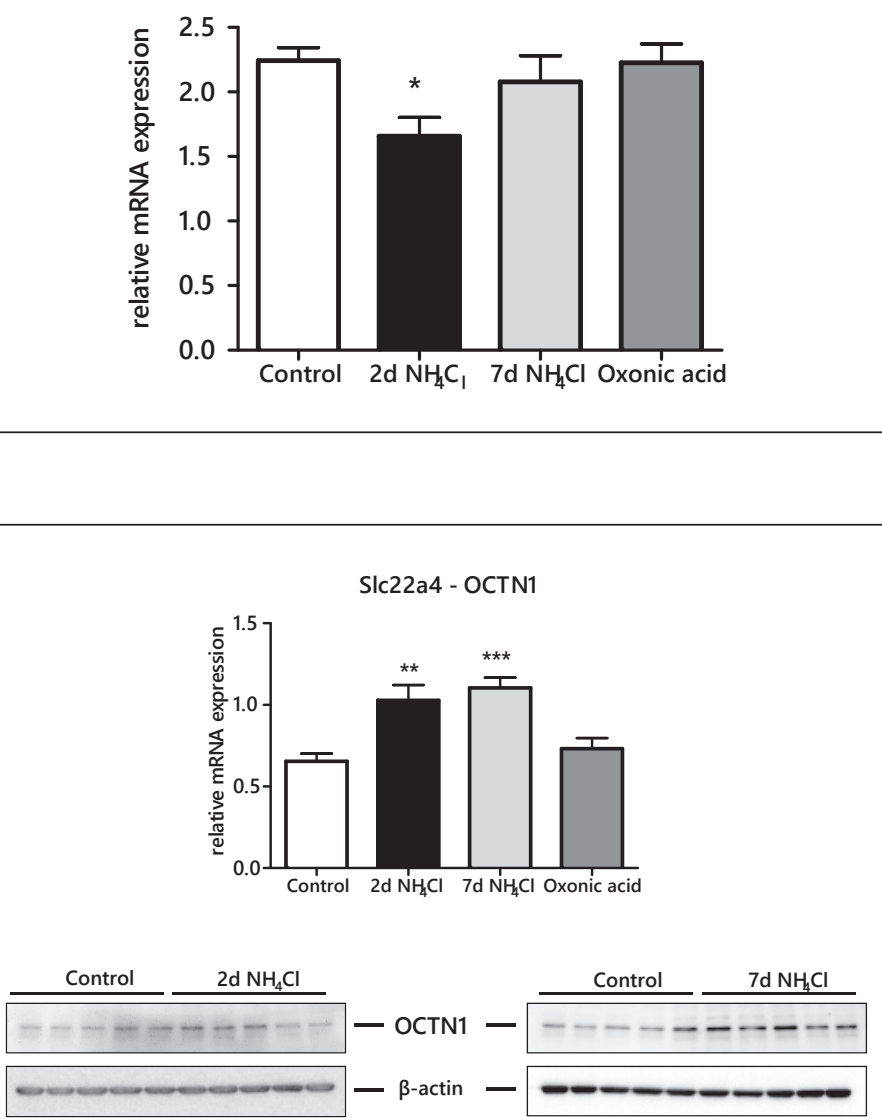

Control Oxonic acid
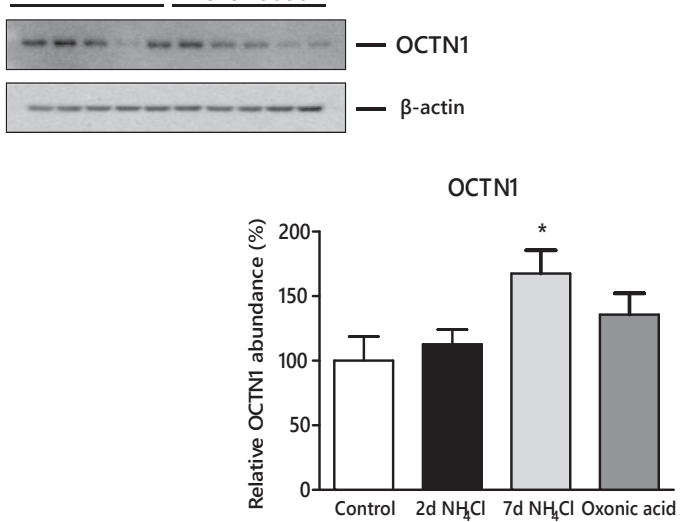

$\mathrm{NH}_{4} \mathrm{Cl}$ significantly increased the mRNA abundance of the Octn1 (Slc22a4) both after 2 and 7 days. Similarly, Octn 1 protein abundance was higher after 7 days of $\mathrm{NH}_{4} \mathrm{Cl}$. Oxonic acid did not modulate Slc22a4 mRNA or protein abundance (Fig. 3).

Induction of acidosis also changed the mRNA and protein expression of the Oat1 (Slc22a6; Fig. 4). $\mathrm{NH}_{4} \mathrm{Cl}$ transiently but significantly reduced both mRNA and protein abundance after 2 days, whereas after 7 days mRNA and protein expression levels had returned 


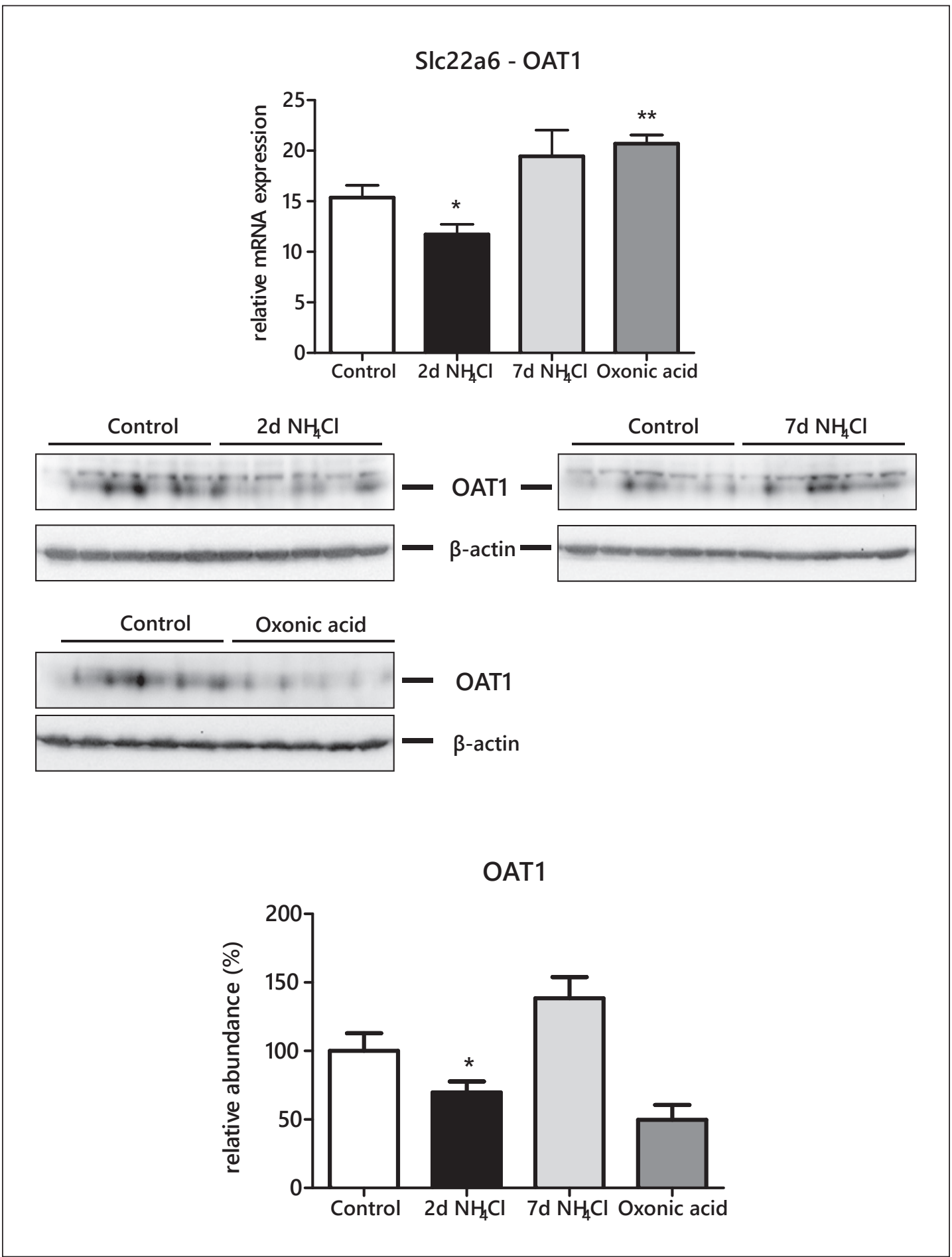

Fig. 4. Regulation of the Oat1 anion transporter in mouse kidney. Semi-quantitative RT-PCR was performed on total mRNA and immunoblotting on total membranes extracted from kidneys from control mice, mice receiving $\mathrm{NH}_{4} \mathrm{Cl}$ for 2 or 7 days, and mice receiving 2\% oxonic acid. Membranes were stripped and reprobed for $\beta$-actin to control for loading. Bar graphs show Oat1 protein abundance normalized to $\beta$-actin and expressed as percentage of the control group. $n=5 /$ group, ${ }^{*} p<0.05,{ }^{* *} p<0.01$. OCT, organic cation transporter; SLC22, solute carrier family 22. 
Kidney

Blood Pressure

Research

Fig. 5. Expression of the OAT5 in mouse kidney. Semi-quantitative RT-PCR was performed on total mRNA extracted from kidneys from control mice, mice receiving $\mathrm{NH}_{4} \mathrm{Cl}$ for 2 or 7 days, and mice receiving $2 \%$ oxonic acid. $n=5 /$ group, $* p<0.05$, ${ }^{* *} p<0.01$. OCT, organic cation transporter; SLC22, solute carrier family 22.

Fig. 6. Regulation of the Urat1 urate transporter in mouse kidney. Semi-quantitative RT-PCR was performed on total mRNA and immunoblotting on brush border membranes extracted from kidneys from control mice, mice receiving $\mathrm{NH}_{4} \mathrm{Cl}$ for 2 or 7 days, and mice receiving $2 \%$ oxonic acid. Membranes were stripped and reprobed for $\beta$-actin to control for loading. Bar graphs show Urat1 protein abundance normalized to $\beta$-actin and expressed as percentage of the control group. $n=5 /$ group, ${ }^{*} p<0.05$, ** $p<0.01$, *** $p<0.001$. SLC22, solute carrier family 22 .

\begin{tabular}{|c|c|}
\hline \multicolumn{2}{|c|}{ Kidney Blood Press Res 2020;45:263-274 } \\
\hline DOI: $10.1159 / 000506052$ & $\begin{array}{l}\text { (c) } 2020 \text { The Author(s). Published by S. Karger AG, Basel } \\
\text { www.karger.com/kbr }\end{array}$ \\
\hline
\end{tabular}
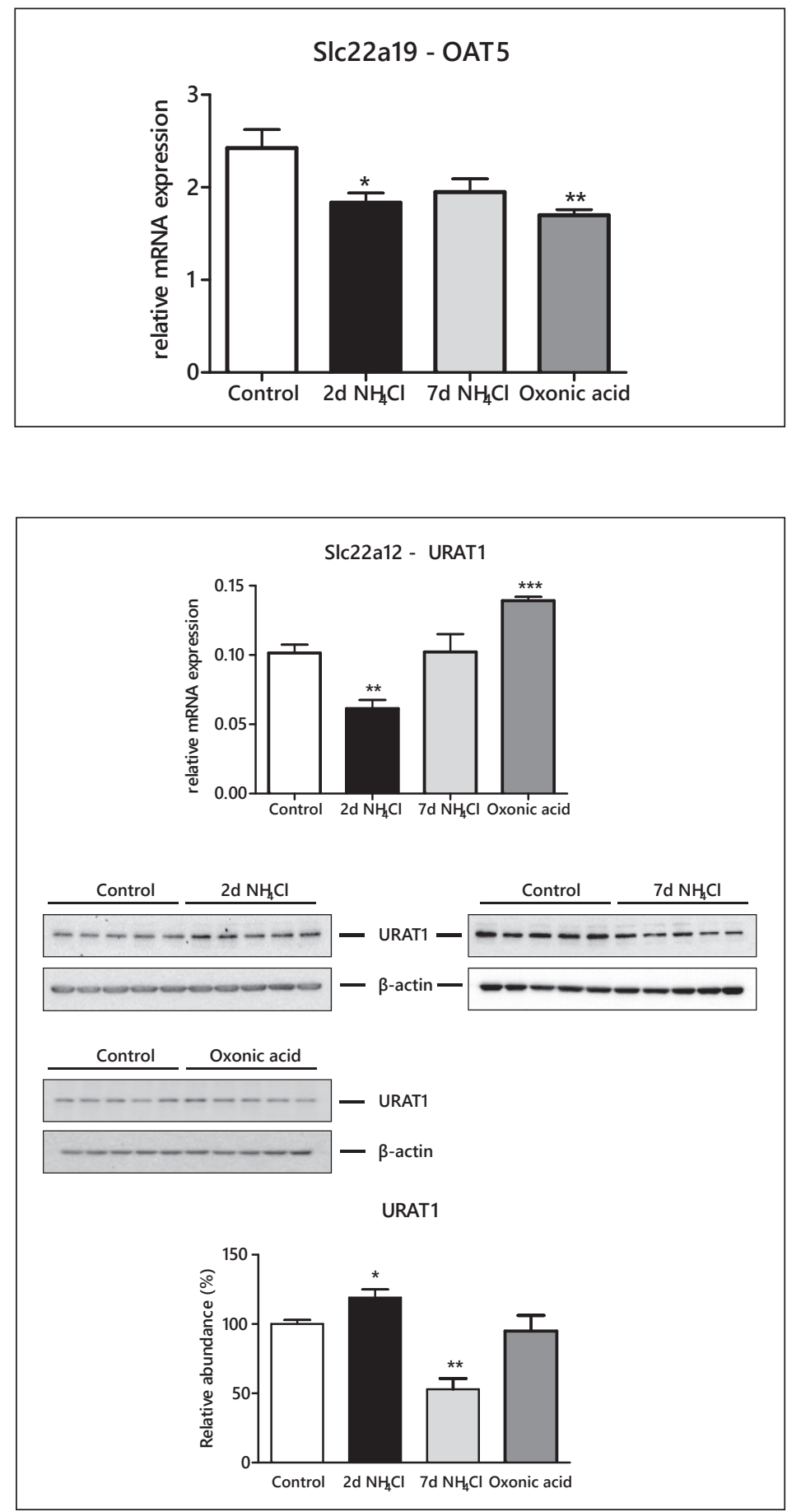

to baseline. Oxonic acid increased Slc22a4 mRNA abundance; however, this effect was not seen on protein levels.

$\mathrm{NH}_{4} \mathrm{Cl}$ and oxonic acid decreased Slc22a19 (Oat5) mRNA expression (Fig. 5), the effects on protein abundance could not be tested due to lack of specific antibodies.

Last, we assessed the effects of $\mathrm{NH}_{4} \mathrm{Cl}$ and oxonic acid on the expression of the Urat1 urate transporter (Fig. 6). While 2 days of $\mathrm{NH}_{4} \mathrm{Cl}$ decreased and 7 days of oxonic acid increased 


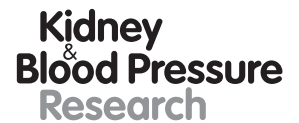

Research

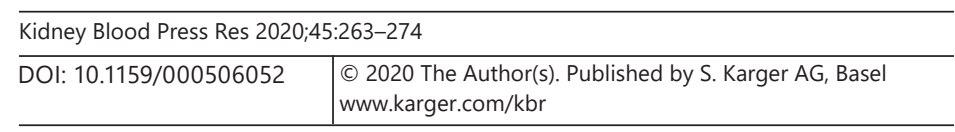

Gottier Nwafor et al.: Metabolic Acidosis Alters Expression of Slc22 Transporters in Mouse Kidney

Slc22a12 mRNA expression levels, 2 days of $\mathrm{NH}_{4} \mathrm{Cl}$ slightly increased and 7 days of $\mathrm{NH}_{4} \mathrm{Cl}$ strongly decreased Urat1 protein abundance. Oxonic acid had no apparent effect on Urat1 protein expression levels.

\section{Discussion}

The kidneys have a central role in the elimination of water-soluble endogenous and exogenous waste products and drugs. Members of the Slc22 family of anion and cation transporters play a critical role in this process. Their activity is regulated by various factors including hormones, metabolites, and also gut microbiome-derived signals [2,15-17] Here we provide additional evidence for regulation by systemic acid-base status. Our data provide evidence for the acute and partly transient regulation of several members of the Slc22 family during metabolic acidosis.

We show here that the apical Octn1 transporter is upregulated during chronic metabolic acidosis on protein level. This is preceded and paralleled by increased mRNA abundance of this transporter. Protein expression of the basolateral Oat1 transporter is transiently reduced during acute ( 2 days) metabolic acidosis but returns to baseline after 7 days acidosis. Also this is paralleled by similar mRNA abundance of Oat1. Also Urat1 showed the same course of protein and mRNA expression with a transient reduction after 2 days metabolic acidosis. In case of the Oct1 and Oat 5 transporters only mRNA levels could be examined and both showed lower mRNA abundance during the acute phase of metabolic acidosis. Oct1 mRNA returned to baseline, whereas 0 at 5 remained lower with more prolonged acidosis. Inhibition of uricase activity with oxonic acid had surprisingly no effect on plasma uric acid levels and reduced 24 $\mathrm{h}$ uric acid excretion. Oxonic acid had no effect on Oct1 mRNA, Octn1 mRNA, and protein levels but increased Urat1 and Oat1 mRNA levels (without altering URAT1 protein levels) and lowered Oat5 mRNA abundance. Thus, reduced urinary uric acid excretion is not paralleled by changes in the abundance of the URAT1 transporter.

Changes in mRNA and protein expression of the Slc22 transporters investigated did not always parallel [3]. This was particularly obvious for URAT1. Different processes regulate transcription and translation and metabolic acidosis has been shown to impact on both processes through modulation of transcription factors as well as by altering translation or posttranslational modifications $[18,19]$. In case of Slc22 transporters, the correlation between mRNA or protein expression and ultimate activity in proximal tubular cells may be even more difficult as the functional activity of several members of the this transporter family is highly regulated by a complex network of kinases altering transport activity within minutes presumably without affecting protein abundance [15]. Whether acidosis impacts on these signaling cascades and their ability to regulate Slc22 transporters remains to be investigated.

Our results confirm and extend data from a previous report that showed an acute acid load (comparable to our 2 days metabolic acidosis) caused downregulation of Oat3 protein (not tested here) and did not affect Oat1 and Oct2 protein levels. We had not tested for Oat1 protein abundance and Oct2 had not been included in our panel of transporters tested as it had not been regulated on mRNA levels in our previous genome wide screen for renal transcripts altered during metabolic acidosis [3]. However, Gaowa et al. [4] demonstrate that metabolic acidosis has a relevant impact on plasma levels of 2 substances that are at least in part eliminated by members of the Slc22 family, metformin and phenolsulfonphthalein. Phenolsulfonphthalein and metformin levels in plasma were elevated after 2 days of metabolic acidosis indicating reduced active secretion consistent with downregulation of Slc22 transporters [3]. Thus, metabolic acidosis has a relevant impact on Slc22 transporter mediated drug and metabolite clearance. 
Some members of the Slc22 transporter family such as Oat1 and 3 couple the transport of drugs or metabolites to the exchange against $\alpha$-ketoglutarate $[2,20]$. Transport of a-ketoglutrate is also coupled via the TCA cycle to cellular lactate levels [21]. Of note, the urinary excretion of $\alpha$-ketoglutarate and lactate as well as the expression of several lactate transporters from the Slc5 and 16 monocarboxylate transporter families is also affected by metabolic acidosis [22, 23]. It is thus conceivable that the effect of acidosis on the ability of the proximal tubule to secrete drugs and metabolites involves not only downregulation of Slc22 drug transporters but also transporters and metabolic pathways that provide substrate for obligatory exchange via Oat transporters.

In summary, we demonstrate that the expression levels of several renal proximal tubular transporters are altered during metabolic acidosis. This is consistent with changes also in metabolites transported by some of these transporters as well as with altered pharmacokinetics of prototypical substrates of these transporters. Thus, acid-base status may be a relevant factor affecting pharmacokinetics of drugs eliminated by transporters sensitive to acid-base status.

\section{Acknowledgments}

The use of the ZIHP Core Facility for Rodent Physiology is gratefully acknowledged.

\section{Statement of Ethics}

No ethical approval required for these studies. All animal experiments were approved by the local Veterinary Authority and complied with Swiss Animal Welfare Laws.

\section{Disclosure Statement}

The authors declare no conflict of interest.

\section{Funding Sources}

This study was supported by grants from the Swiss National Science Foundation to C.A.W. (155959 and 176125). This work was further supported in part by grants from the Science Research Promotion Fund of the Japan Private School Promotion Foundation (to H.E.), grants from the Japan Society for the Promotion of Science (KAKENHI 26461258, 18K08200), and Gout Research Foundation of Japan (to N.A.).

\section{Author Contributions}

J.G.N. and M.N. performed experiments. H.E. and N.A. provided materials. C.A.W. planned experiments. J.G.N., M.N., and C.A.W. wrote the manuscript. All authors read and approved the manuscript. 


\section{Kidney \\ Blood Pressure \\ Research}

\begin{tabular}{l|l}
\hline Kidney Blood Press Res 2020;45:263-274 \\
\hline DOI: 10.1159/000506052 & $\begin{array}{l}\text { @ 2020 The Author(s). Published by S. Karger AG, Basel } \\
\text { www.karger.com/kbr }\end{array}$ \\
\hline
\end{tabular}

Gottier Nwafor et al.: Metabolic Acidosis Alters Expression of Slc22 Transporters in Mouse Kidney

\section{References}

1 Koepsell H, Endou H. The SLC22 drug transporter family. Pflugers Arch. 2004 Feb;447(5):666-76.

2 Nigam SK. The SLC22 Transporter Family: A Paradigm for the Impact of Drug Transporters on Metabolic Pathways, Signaling, and Disease. Annu Rev Pharmacol Toxicol. 2018 Jan;58(1):663-87.

3 Nowik M, Lecca MR, Velic A, Rehrauer H, Brändli AW, Wagner CA. Genome-wide gene expression profiling reveals renal genes regulated during metabolic acidosis. Physiol Genomics. 2008 Feb;32(3):322-34.

4 Gaowa A, Motohashi H, Katsura T, Inui K. Effects of metabolic acidosis on expression levels of renal drug transporters. Pharm Res. 2011 May;28(5):1023-30.

5 Kang DH, Nakagawa T, Feng L, Watanabe S, Han L, Mazzali M, et al. A role for uric acid in the progression of renal disease. J Am Soc Nephrol. 2002 Dec;13(12):2888-97.

6 Seaton B, Ali A. Simplified manual high performance clinical chemistry methods for developing countries. Med Lab Sci. 1984 Oct;41(4):327-36.

7 Berthelot M. Violet d'aniline. Rep Chim App. 1859;1:284.

8 Biber J, Stieger B, Haase W, Murer H. A high yield preparation for rat kidney brush border membranes. Different behaviour of lysosomal markers. Biochim Biophys Acta. 1981 Oct;647(2):169-76.

9 Biber J, Stieger B, Stange G, Murer H. Isolation of renal proximal tubular brush-border membranes. Nat Protoc. 2007;2(6):1356-9.

10 Wagner CA, Finberg KE, Stehberger PA, Lifton RP, Giebisch GH, Aronson PS, et al. Regulation of the expression of the $\mathrm{Cl}$-/anion exchanger pendrin in mouse kidney by acid-base status. Kidney Int. 2002 Dec;62(6):2109-17.

11 Enomoto A, Kimura H, Chairoungdua A, Shigeta Y, Jutabha P, Cha SH, et al. Molecular identification of a renal urate anion exchanger that regulates blood urate levels. Nature. 2002 May;417(6887):447-52.

12 Nowik M, Kampik NB, Mihailova M, Eladari D, Wagner CA. Induction of metabolic acidosis with ammonium chloride $(\mathrm{NH} 4 \mathrm{Cl})$ in mice and rats-species differences and technical considerations. Cell Physiol Biochem. 2010;26(6):1059-72.

13 Mumtaz R, Trepiccione F, Hennings JC, Huebner AK, Serbin B, Picard N, et al. Intercalated Cell Depletion and Vacuolar H+-ATPase Mistargeting in an Ae1 R607H Knockin Model. J Am Soc Nephrol. 2017 May;28(5):1507-20.

14 López-Cayuqueo KI, Chavez-Canales M, Pillot A, Houillier P, Jayat M, Baraka-Vidot J, et al. A mouse model of pseudohypoaldosteronism type II reveals a novel mechanism of renal tubular acidosis. Kidney Int. 2018 Sep; 94(3):514-23.

15 Holle SK, Ciarimboli G, Edemir B, Neugebauer U, Pavenstädt H, Schlatter E. Properties and regulation of organic cation transport in freshly isolated mouse proximal tubules analyzed with a fluorescence reader-based method. Pflugers Arch. 2011 Aug;462(2):359-69.

16 Jansen J, Jansen K, Neven E, Poesen R, Othman A, van Mil A, et al. Remote sensing and signaling in kidney proximal tubules stimulates gut microbiome-derived organic anion secretion. Proc Natl Acad Sci USA. 2019 Aug;116(32):16105-10.

17 Rosenthal SB, Bush KT, Nigam SK. A Network of SLC and ABC Transporter and DME Genes Involved in Remote Sensing and Signaling in the Gut-Liver-Kidney Axis. Sci Rep. 2019 Aug;9(1):11879.

18 Izumi Y, Inoue H, Nakayama Y, Eguchi K, Yasuoka Y, Matsuo N, et al. TSS-Seq analysis of low pH-induced gene expression in intercalated cells in the renal collecting duct. PLoS One. 2017 Aug;12(8):e0184185.

19 Lister A, Bourgeois S, Imenez Silva PH, Rubio-Aliaga I, Marbet P, Walsh J, et al. NRF2 regulates the glutamine transporter Slc38a3 (SNAT3) in kidney in response to metabolic acidosis. Sci Rep. 2018 Apr;8(1):5629.

20 Henjakovic M, Hagos Y, Krick W, Burckhardt G, Burckhardt BC. Human organic anion transporter 2 is distinct from organic anion transporters 1 and 3 with respect to transport function. Am J Physiol Renal Physiol. 2015 Nov;309(10):F843-51.

21 Vriend J, Hoogstraten CA, Venrooij KR, van den Berge BT, Govers LP, van Rooij A, et al. Organic anion transporters 1 and 3 influence cellular energy metabolism in renal proximal tubule cells. Biol Chem. 2019 Sep; 400(10):1347-58.

22 Becker HM, Mohebbi N, Perna A, Ganapathy V, Capasso G, Wagner CA. Localization of members of MCT monocarboxylate transporter family Slc16 in the kidney and regulation during metabolic acidosis. Am J Physiol Renal Physiol. 2010 Jul;299(1):F141-54.

23 Tokonami N, Morla L, Centeno G, Mordasini D, Ramakrishnan SK, Nikolaeva S, et al. $\alpha$-Ketoglutarate regulates acid-base balance through an intrarenal paracrine mechanism. J Clin Invest. 2013 Jul;123(7):3166-71. 